\title{
Identification and Characterization of a Gene Regulating Enzymatic Glycosylation which is Induced by Diabetes and Hyperglycemia Specifically in Rat Cardiac Tissue
}

\author{
Yoshihiko Nishio, ${ }^{\star}$ Charles E. Warren, ${ }^{\star}$ Jo Ann Buczek-Thomas, $\$$ Jill Rulfs, ${ }^{\$}$ Daisuke Koya, ${ }^{*}$ Lloyd P. Aiello, ${ }^{\star}$ \\ Edward P. Feener, ${ }^{*}$ Thomas B. Miller, Jr., James W. Dennis, ${ }^{\star}{ }^{5}$ and George L. King ${ }^{*}$ \\ *Research Division, Joslin Diabetes Center, and Departments of Medicine, Harvard Medical School and Brigham and Women's \\ Hospital, Boston, Massachusetts, 02215; ${ }^{\ddagger}$ Samuel Lunenfeld Research Institute, Mount Sinai Hospital, Toronto, Canada M5G 1X5; and \\ ${ }^{\S}$ Department of Biochemistry and Molecular Biology, University of Massachusetts Medical School, Worcester, Massachusetts, 01655
}

\begin{abstract}
Primary cardiac abnormalities have been frequently reported in patients with diabetes probably due to metabolic consequences of the disease. Approximately 2,000 mRNA species from the heart of streptozotocin-induced diabetic and control rats were compared by the mRNA differential display method, two of eight candidate clones thus isolated (DH1 and 13) were confirmed by Northern blot analysis. The expression of clone 13 was increased in the heart by 3.5-fold $(P<0.05)$ and decreased in the aorta by twofold $(P<0.05)$ in diabetes as compared to control. Sequence analysis showed that clone 13 is a rat mitochondrial gene. DH1 was predominantly expressed in the heart with an expression level 6.8-fold higher in the diabetic rats than in control $(P<0.001)$. Insulin treatment significantly $(P$ $<0.001$ ) normalized the expression of DH1 in the hearts of diabetic rats. DH1 expression was observed in cultured rat cardiomyocytes, but not in aortic smooth muscle cells or in cardiac derived fibroblasts. The expression in cardiomyocytes was regulated by insulin and glucose concentration of culture media. The full length cDNA of DH1 had a single open-reading frame with 85 and $92 \%$ amino acid identity to human and mouse UDP-GIcNAc:Galß1-3GalNAcaR $\beta 1$ $6 \mathrm{~N}$-acetylglucosaminyltransferase (core 2 GlcNAc-T), respectively, a key enzyme determining the structure of $O$ linked glycosylation. Transient transfection of DH1 cDNA into Cos7 cells conferred core 2 GlcNAc-T enzyme activity. In vivo, core 2 GlcNAc-T activity was increased by $82 \%$ ( $P$ $<0.05)$ in diabetic hearts vs controls, while the enzymes GlcNAc-TI and GlcNAc-TV responsible for $\boldsymbol{N}$-linked glycosylation were unchanged. These results suggest that core 2 GlcNAc-T is specifically induced in the heart by diabetes or hyperglycemia. The induction of this enzyme may be responsible for the increase in the deposition of glycoconjugates and the abnormal functions found in the hearts of diabetic rats. (J. Clin. Invest. 1995. 96:1759-1767.) Key words: glycosylation - cardiomyopathy - cardiomyocytes • diabetic complications $\bullet$ gene regulation
\end{abstract}

Address correspondence to George L. King, Research Division, Joslin Diabetes Center, One Joslin Place, Boston, MA, 02215. Phone: 617732-2622; FAX: 617-732-2637; E-mail: KingG@Joslab.Harvard.edu.

Received for publication 29 March 1995 and accepted in revised form 22 June 1995.

J. Clin. Invest.

(C) The American Society for Clinical Investigation, Inc.

0021-9738/95/10/1759/09 \$2.00

Volume 96, October 1995, 1759-1767

\section{Introduction}

Cardiovascular diseases are the major cause of morbidity and mortality in diabetic patients, involving cardiac tissues as well as large vessels in the brain, heart, and lower extremities (1). In the heart, the majority of the cardiac failure is probably due to atherosclerotic processes in the coronary vessels, but multiple studies have documented that a sizeable number of diabetic patients suffer from congestive heart failure without significant coronary disease $(2,3)$. In addition, type I diabetic patients with $<5 \mathrm{yr}$ of disease have been reported to have abnormal cardiac function in the absence of significant coronary vessel disease (4). These clinical findings are supported further by animal studies documenting biochemical and functional changes in the cardiac tissue shortly after induction of diabetes (5-8). From these results, it has been postulated that diabetes mellitus and its metabolic sequelae can induce a specific form of cardiomyopathy $(8,9)$.

As with other chronic complications of diabetes, the cardiovascular changes once established are difficult to reverse, both in clinical and experimental settings (10-12). Most cardiovascular abnormalities are metabolically induced, with a great deal of interest directed towards identifying alterations in gene expression induced by diabetes or hyperglycemia in the vasculature. Since thickening of basement membrane is a classical finding in diabetic microvasculature (10), many of the studies concerning glucose-regulated genes have primarily focused on changes in the basement matrix components using cultured vascular cells $(13,14)$. In contrast, we investigated the effect of diabetes on gene expression in cardiac tissue. We adapted mRNA differential display (developed by Liang and Pardee to identify novel oncogenes in tumor cells $[15,16])$, to identify changes in gene expression induced by metabolic stimuli such as hyperglycemia or diabetes $(17,18)$. We have succeeded in characterizing several clones which are differentially expressed in the ventricles of streptozotocin (STZ) ${ }^{1}$ diabetic rats. One clone (DH1) was sequenced, identified, and studied further since its genetic expression in cardiomyocytes was regulated by hyperglycemia and insulin.

\section{Methods}

Animals. Male Sprague-Dawley rats (Taconic Farms, Inc. German Town, NY) weighing 180-200 grams were injected by the intraperitoneal route with STZ ( $80 \mathrm{mg} / \mathrm{kg}$ of body weight). STZ was dissolved

1. Abbreviations used in this paper: Core 2 GlcNAc-T, UDPGlcNAc:Gal $\beta 1-3 G$ alNAc $\alpha \beta 1-6 N$-acetylglucosaminyltransferase; NOD, nonobese diabetic; PAS, periodic acid Schiff; STZ, streptozotocin. 
in $20 \mathrm{mM}$ citrate buffer ( $\mathrm{pH} 4.5$ ) immediately before use. Cardiac tissue from spontaneous autoimmune-caused diabetic nonobese diabetic (NOD) mice and their control littermates were graciously provided by Dr. Masakazu Hattori of the Joslin Diabetes Center (Boston, MA) (19). Onset of diabetes was determined by the detection of urinary glucose and confirmed by blood glucose levels. Insulin pellets (Linshin, Scarborough, Canada) were implanted subcutaneously $1 \mathrm{wk}$ after STZ injection in four STZ-diabetic rats for another week to normalize blood glucose levels. The mean plasma blood glucose level in insulin-treated STZdiabetic rats was not significantly different from control animals ( $4.8 \pm 0.5$ vs $5.6 \pm 0.7 \mathrm{mM}$ ), while, the mean body weight in the insulintreated STZ-diabetic rats remained significantly less than control $(270 \pm 17$ vs $326 \pm 17$ grams respectively, $P<0.01)$ but significantly greater than diabetic rats without insulin treatment $(210 \pm 33$ grams $)$, $(P<0.01)$.

$m R N A$ differential display. Rats were killed 2 wk after onset of diabetes. Cardiac ventricles and thoracic aorta were dissected and washed with ice-cold PBS, immediately frozen in liquid $\mathrm{N}_{2}$, then crushed into frozen powder. Pieces of aorta from three rats were combined into one sample. Total RNA was extracted using Ultraspec RNA isolation system (Biotecx Laboratories, Houston, TX). mRNA differential display was performed as previously reported $(17,18)$. Briefly, DNA-free RNA was obtained by treatment with DNase I (GIBCO BRL, Grand Island, NY) in the presence of placental RNase inhibitor (GIBCO $\mathrm{BRL}$ ) for $30 \mathrm{~min}$ at $37^{\circ} \mathrm{C}$. After phenol/chloroform extraction and ethanol precipitation, two reverse transcriptions were performed for each RNA sample using $0.2 \mu \mathrm{g}$ DNA-free total RNA in $1 \times$ reverse transcription buffer (PCR buffer) containing $10 \mathrm{mM}$ DTT, $20 \mu \mathrm{M}$ each of dGTP, dATP, dTTP, and dCTP, and $1 \mu \mathrm{M}$ of either $\mathrm{T}_{12} \mathrm{NG}$ or $\mathrm{T}_{12} \mathrm{NC}$ oligonucleotide (Midland Certified Reagent Co., Midland, TX) where $\mathrm{N}$ is threefold degenerate for $\mathrm{G}, \mathrm{A}$, and $\mathrm{C}$. The solution was heated at $65^{\circ} \mathrm{C}$ for $5 \mathrm{~min}$ and cooled to $37^{\circ} \mathrm{C}$, then superscript reverse transcriptase ( $20 \mathrm{U}$ ) (GIBCO BRL) was added for $1 \mathrm{~h}$. PCR was performed in reaction mixtures containing $0.1 \mathrm{vol}$ of reverse transcription reaction mixture, $1 \times$ PCR buffer, $2 \mu \mathrm{M}$ each of dGTP, dATP, dTTP, and dCTP, $10 \mu \mathrm{Ci}\left[\alpha-{ }^{35} \mathrm{~S}\right]$-dATP, $1 \mu \mathrm{M}$ of the respective $\mathrm{T}_{12} \mathrm{NX}$ oligonucleotide, $0.2 \mu \mathrm{M}$ of 20 different specific arbitrary 10-mer oligonucleotides (OPERON Technologies Inc., Almeda, CA) and $10 \mathrm{U}$ of AmpliTaq DNA polymerase (Perkin-Elmer Cetus Corp. Norwalk, CT). The PCR reactions were initiated at $95^{\circ} \mathrm{C}$ for $1 \mathrm{~min}$, amplified 40 cycles at $94^{\circ} \mathrm{C}$ for $45 \mathrm{~s}, 40^{\circ} \mathrm{C}$ for $90 \mathrm{~s}, 72^{\circ} \mathrm{C}$ for $30 \mathrm{~s}$, and finished at $72^{\circ} \mathrm{C}$ for $15 \mathrm{~min}$. DNA sequencing stop buffer (U.S. Biochemical, Inc., Cleveland, $\mathrm{OH}$ ) was added to samples which were heated at $80^{\circ} \mathrm{C}$ for 2 min before loading on a $6 \%$ polyacrylamide sequencing gel (National Diagnostics, Atlanta, GA). After electrophoresis, the gels were exposed to XAR-5 film (Eastman Kodak Co., Rochester NY) for $48 \mathrm{~h}$. Bands evident under one glycemic condition and absent in the other were identified and the PCR repeated to confirm the findings.

Band recovery and Northern blot analysis. Bands reproducibly exhibiting significant differences in expression were cut out and DNA was eluted by boiling in $10 \mathrm{mM}$ Tris $\mathrm{HCl}$ and $1 \mathrm{mM}$ EDTA solution for 30 min. After ethanol precipitation, the DNA was reamplified by PCR using appropriate primers and conditions described above except for dNTP concentrations of $20 \mu \mathrm{M}$ and no radioisotope. Products were visualized on $2 \%$ agarose gels, eluted, and used as probes for Northern blot analysis or subcloned. Total RNA (20-25 $\mu \mathrm{g}$ ) was fractionated by denaturing $1 \%$ formaldehyde agarose gel electrophoresis and transferred to Biotrans nylon membrane (ICN, Irvine, CA). ${ }^{32} \mathrm{P}$-labeled probes prepared by random priming using a commercially available kit (Amersham Corp., Arlington Heights, IL) were hybridized to UV cross-linked blots in $0.1 \mathrm{M}$ Pipes, 0.2 $\mathrm{M} \mathrm{NaPO}_{4}, 0.1 \mathrm{M} \mathrm{NaCl}, 1 \mathrm{mM}$ EDTA, 5\% SDS, and $60 \mu \mathrm{g} / \mathrm{ml}$ salmon sperm DNA at $65^{\circ} \mathrm{C}$ and washed in 0.5 $\times \mathrm{SSC}, 5 \% \mathrm{SDS}$ at $65^{\circ} \mathrm{C}$ for over $1 \mathrm{~h}$. mRNA expression was quantified using a phosphorImager and standardized volume integration with the accompanying ImageQuant Analyzing Software version 3.3 (Molecular Dynamics, Sunnyvale, CA) and loading differences were normalized using 36B4 as standard cDNA probe $(17,18)$.

DNA sequencing. Samples showing significant changes by Northern blot analysis were subcloned using the TA Cloning Kit (Invitrogen
Corp., San Diego, CA). After the subcloned inserts were checked by Northern blot analysis, DNA sequencing was performed using commercially available Sequenase version 2.0 kit (U.S. Biochemical, Inc.). Gene database searches were performed at the National Center for Biotechnology Information (NCBI) using the BLAST network service.

Construction of the diabetic heart cDNA library. Poly(A) + RNA was isolated from the total cellular RNA extracted from heart of diabetic rats using an oligo-dT cellulose column (Pharmacia LKB Biotechnology Piscataway, $\mathrm{NJ}$ ) as previously described (17). cDNA was prepared and ligated into the EcoRI sites of Lambda gt10 (Stratagene, Inc., La Jolla, CA) by standard methods (20). After packaging the DNA, Escherichia coli (C600) was infected with the phage and plated on a P150 plate yielding about $5 \times 10^{4}$ independent plaque-forming units. Plaques were lifted onto nitrocellulose (Schleicher \& Schuell, Inc., Keene, NH) and cross-linked to the membrane by ultraviolet light. 20 P150 plates were screened, which provided $1 \times 10^{6}$ plaque-forming units for screening.

Screening the cDNA library. A 214-bp cDNA (DH1) probe obtained from differential display was hybridized to the cDNA library by standard methods at $44^{\circ} \mathrm{C}$ then washed at $56^{\circ} \mathrm{C}(21)$. After screening $1 \times 10^{6}$ plaque-forming units, a positive cDNA insert was isolated and subcloned into pBluescript (Stratagene, Inc.). For sequencing, the inserts were restricted using BamH1 and EcoRI and subcloned into pBluescript.

cDNA cloning of mouse UDP-GlcNAc:Gal $\beta 1-3 G a l N A c \alpha R ~ \beta 1-6 N$ acetylglucosaminyltransferase (core 2 GlcNAc-T). Approximately 2 $\times 10^{5}$ colonies of a cDNA library prepared in pCDM8 (Invitrogen Corp.) using poly A+ RNA from D33W25, a murine lymphoid tumor cell line (22), were screened by colony hybridization (23) to a 864-bp EcoRI-BamH1 subcloned fragment of human core 2 GlcNAc-T isolated by PCR (gift of Dr. A. Datti, Perugia, Italy) corresponding to amino acids 85-372 of the human enzyme. Hybridization was performed overnight at $65^{\circ} \mathrm{C}$ in $500 \mathrm{mM}$ sodium phosphate $\mathrm{pH} 7.2,7 \%$ SDS, $1 \%$ BSA, $1 \mathrm{mM}$ EDTA. After rinsing, filters were washed at $65^{\circ} \mathrm{C}$ in $100 \mathrm{mM}$ sodium phosphate, $0.1 \%$ SDS. After three rounds of hybridization and purification, two clones, designated C2-251 and C2-352, were isolated and gave specific and strongly positive signals on Southern blots hybridized with the probe. The cDNA inserts were subcloned as XhoI fragments into Sal I cut pGEM5zf $(+)$ (Promega Corp., Madison, WI) and a series of exonuclease III-mung bean nuclease (GIBCO BRL) -nested deletions generated from each end. DNA sequencing was performed using the Autoread sequencing kit and the ALF DNA sequencer according to the manufacturer's instructions (Pharmacia LKB Biotechnology). Some sequences were also generated using internal primers. Data were analyzed and edited using the UWGCG suite.

Transient expression of $\mathrm{DH} 1$ in Cos 7 cells. A cDNA insert containing the full open reading frame of DH1 was isolated with XhoI and EcoRV and subcloned into pcDNAI/amp (Invitrogen Corp.). The plasmid was purified by double $\mathrm{CsCl}$ ultracentrifugation followed by phenol/chloroform extraction (21), then DNA $(0.5 \mu \mathrm{g})$ was transfected into nonconfluent $\operatorname{Cos} 7$ cells cultured on P100 dishes using $20 \mu \mathrm{g}$ of Lipofectin for $16 \mathrm{~h}$ at $37^{\circ} \mathrm{C}$ (GIBCO BRL) (24). Cells were harvested $48 \mathrm{~h}$ later and used for measurement of core 2 GlcNAc transferase activity.

Preparation of cardiomyocytes. Cardiomyocytes were prepared by collagenase digestion as described before (25). Briefly, hearts were excised and perfused through the aorta with Krebs-Henseleit bicarbonate buffer containing $5.5 \mathrm{mM}$ glucose and $2.5 \mathrm{mM}$ calcium. The perfused medium was switched to the same buffer without calcium to stop contraction, followed by a final perfusion with Krebs-Henseleit buffer containing $50 \mu \mathrm{M}$ calcium, $0.1 \%$ BSA, $312 \mathrm{U} / \mathrm{ml}$ hyaluronidase (Worthington, Freehold, $\mathrm{NJ}$ ) and $0.1 \%$ collagenase (Worthington). Ventricular tissue was dissociated by shaking in Krebs-Henseleit buffer containing $50 \mu \mathrm{M}$ calcium, $0.2 \% \mathrm{BSA}, 312 \mathrm{U} / \mathrm{ml}$ hyaluronidase, and $0.1 \%$ collagenase. The cells were allowed to settle under gravity and were washed twice in the Krebs-Henseleit buffer containing $100 \mu \mathrm{M}$ calcium and $0.5 \%$ BSA before resuspension in minimal essential medium containing Earle's salts, $26 \mathrm{mM}$ sodium bicarbonate, $5 \mathrm{mM}$ creatine, $20 \mathrm{mM}$ Hepes, $100 \mathrm{U} / \mathrm{ml}$ penicillin $\mathrm{G}, 100 \mu \mathrm{g} / \mathrm{ml}$ streptomycin, and $1.8 \mathrm{mM}$ calcium. The cells were seeded onto laminin-coated dishes and maintained in a 
A. Differential
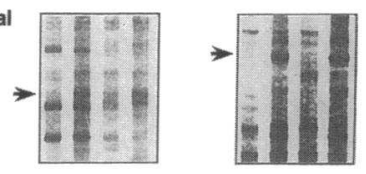

Clone

DH 1

13

B. Northern Blot Analysis
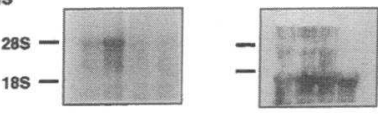

C. $36 \mathrm{~B} 4$

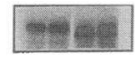

C D C D

Heart Aorta

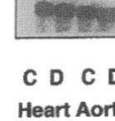

Figure 1. Differential mRNA display $(A)$ and Northern blot analysis ( $B$ and $C$ ) of the differentially expressed cDNA fragments. Candidate cDNA signals which demonstrate altered expression by differential mRNA are marked by arrowheads in (A). (B) Northern blot analysis using $\left[{ }^{32} \mathrm{P}\right] \mathrm{dATP}$ labeled cDNA probes derived from reamplification of molecules marked by arrowheads in $(A)$.

Samples represent $25 \mu \mathrm{g}$ per lane of total cellular RNA isolated from heart ventricles and aorta of either control $(C)$ or diabetic $(D)$ rats.

$37^{\circ} \mathrm{C}$ humidified $95 \%$ air-5\% $\mathrm{CO}_{2}$ incubator. All cells were allowed to equilibrate for $2 \mathrm{~h}$ then washed and refed with the same media containing 0.24 gram \% BSA and cultured for $3 \mathrm{~d}$ with the media changed daily. Some cells were cultured in the same media containing either $22 \mathrm{mM}$ glucose or $10^{-7} \mathrm{M}$ insulin for $3 \mathrm{~d}$ with daily changes of media.

Measurement of core 2 GlcNAc-T activity. Transfected Cos-7 cells were washed in PBS, frozen, thawed, and lysed in $0.9 \% \mathrm{NaCl}, 0.4 \%$ Triton $\mathrm{X}-100$ at $0^{\circ} \mathrm{C}$. PBS-rinsed, fresh frozen rat hearts were rinsed again in PBS and homogenized using a polytron in $0.9 \% \mathrm{NaCl}, 0.4 \%$ Triton X-100, 0.1 mM PMSF, $0.1 \%$ Trasylol at $0^{\circ} \mathrm{C}$. The core $2 \mathrm{GlcNAc}$ transferase reactions contained $50 \mathrm{mM} 2-(N$-morpholino $)$ ethanesulfonic acid (MES) $\mathrm{pH} 7.0,1 \mathrm{mM}$ UDP-GlcNAc, $0.5 \mu \mathrm{Ci}$ UDP-6 $\left[{ }^{3} \mathrm{H}\right]-N$ acetylglucosamine $(16,000 \mathrm{dpm} / \mathrm{nmol}$, New England Nuclear, Boston, MA), $0.1 \mathrm{M}$ GlcNAc, $1 \mathrm{mM}$ of Gal $\beta 1$-3GalNAc $\alpha$-pNp (Toronto Research Chemicals, Toronto, Canada) as substrate, and $16 \mu \mathrm{l}$ of cell lysate $(8-12 \mathrm{mg} / \mathrm{ml}$ of protein) for a final volume of $32 \mu \mathrm{l}(26,27)$. The GlcNAc-TV reactions were the same except that Triton X-100 was added to a final concentration of $1 \%$, and $1 \mathrm{mM}$ of GlcNAc $\beta 1-2 \mathrm{Man} \alpha 1$ $6 \mathrm{Man} \beta 1-\mathrm{O}\left(\mathrm{CH}_{2}\right)_{8} \mathrm{COOCH}_{3}$ (gift of Dr. O. Hindsgaul, University of Alberta, Edmonton, Canada), was used as acceptor (28). The GlcNAcTI reactions were the same as GlcNAc-TV but with the addition of $10 \mathrm{mM} \mathrm{MnCl}{ }_{2}$, and $1 \mathrm{mM} \mathrm{Man} \alpha 1-3(\operatorname{Man} \alpha 1-6) \operatorname{Man} \beta 1-\mathrm{O}\left(\mathrm{CH}_{2}\right)_{8-}$ $\mathrm{COOCH}_{3}$ was used as acceptor (29). Reactions were incubated for either 1 or $2 \mathrm{~h}$ at $37^{\circ} \mathrm{C}$, then diluted to $5 \mathrm{ml}$ in $\mathrm{H}_{2} \mathrm{O}$ and applied to a $\mathrm{C}_{18}$ Sep-Pak (Millipore Corp., Bedford, MA) in $\mathrm{H}_{2} \mathrm{O}$, washed with 20 $\mathrm{ml} \mathrm{H}_{2} \mathrm{O}$. The products were eluted with $5 \mathrm{ml}$ of methanol and radioactivity was counted in a liquid scintillation $\beta$-counter. Endogenous enzymatic activity was measured in the absence of acceptor and subtracted from values determined in the presence of added acceptor.

Statistical analysis. Differences in signal intensity between controls and diabetic animals were expressed as percentage of controls. Because percentages tend to deviate from normal distribution, mean and standard error were calculated after transformation of data to logarithmic values and data were expressed as mean ( \pm SE range). Statistical analysis (Student's $t$ test) was performed using the logarithmic values.

\section{Results}

Differential display. The expression of mRNA species derived from the cardiac ventricles of diabetic and control rats was compared using mRNA differential display. Approximately 2,000, presumably different, mRNA species were screened in this study using 40 combinations of primer sets. As exemplified by Fig. $1 A$, eight candidates appeared differentially expressed when ventricular tissue from control and diabetic rats was compared; five increased and three decreased their expression in the

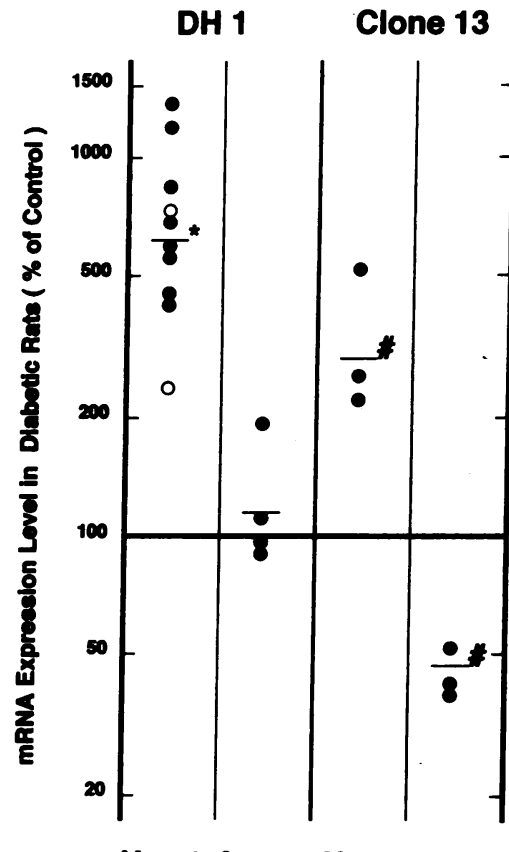

Figure 2. Quantitation of changes induced by diabetes in mRNA level for DH1 and clone 13 in heart and aorta is shown. Data are expressed as percentage of control. Closed circle represents the 2-wk diabetes and open circle represents 1wk diabetes. Each point represents the change in Northern blot analysis using 20-25 $\mu \mathrm{g}$ total cellular RNA obtained from different animals. $* P$ $<0.001,{ }^{*} P<0.05$ compared with control.

diabetic state. These changes were confirmed by repetition at least twice using different preparations of total RNA.

Northern blot analysis. Signals from all the candidates were detectable by Northern blot analysis using total RNA preparations. As shown in Fig. $1 B$, two of the eight candidate species showed significant and reproducible changes in diabetic rats compared to controls. Fig. 2 demonstrates that in rats diabetic for $2 \mathrm{wk}$, the level of DH1 (5.0 kb) increased to 680\% (580$790 \%, n=8, P<0.001$ ) of control in the heart but was not detectable in the aorta. Furthermore, in rats with diabetes for just $1 \mathrm{wk}$, the mRNA level of DH1 in the heart had already significantly increased to $410 \%$ of control levels. A significant increase of DH1 in the heart of diabetic rats was observed even after $4 \mathrm{wk}$ of disease. The expression of clone $13 \mathrm{mRNA}$ increased to $350 \%(260-470 \%, n=3, P<0.05)$ of control in the heart and decreased to $43 \%(38-49 \%, n=3, P<0.05)$ of control in the aorta.

Sequence analysis of $\mathrm{DHI}$ and clone 13. The nucleotide sequences of cDNA fragments of DH1 and clone 13 derived from differential display were determined. Both had flanking primer sequences identical to those used in the differential display. Searching the national gene databases (Gen Bank/EMBL) revealed that clone 13 had $99 \%$ identity to the Wistar rat mitochondrial 16S ribosomal RNA gene (30) while DH1, which was $214 \mathrm{bp}$ in size, did not reveal any homology to previously reported sequences.

Cloning of full-length DHI cDNA. To facilitate identification, a cDNA library derived from diabetic rat heart mRNA was screened using the 214-bp-cloned DH1 PCR fragment as a probe. Five overlapping recombinants were identified and the composite of the full cDNA sequence was determined (Fig. 3 $A$ ). It contained $5,010 \mathrm{bp}$ inclusive of poly $\mathrm{A}$ tail and corresponded to the size detected by the original Northern blot analysis. Open reading frame analysis showed that the longest possible coding region which was from position 802 to 2085 and encoded 428 amino acids. The GXXATGC pattern was observed flanking the region of the presumptive start codon (31) 


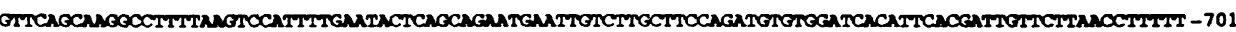
СТСТАМА СеАТАTCA

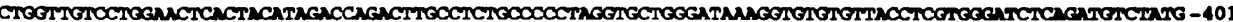

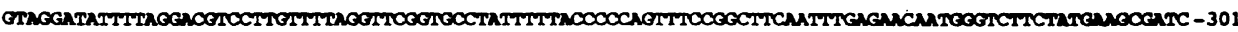

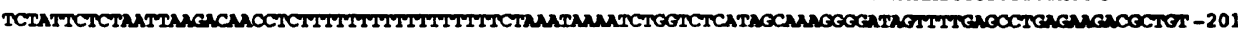

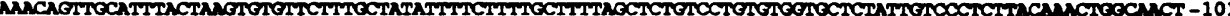

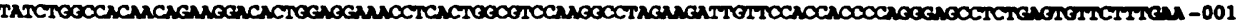

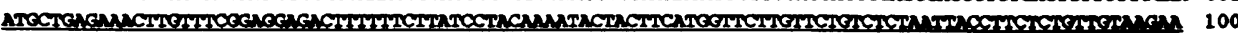

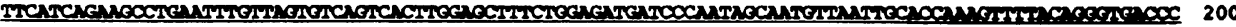

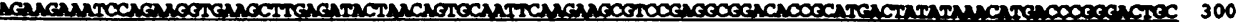

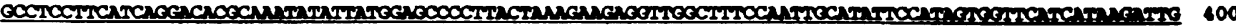

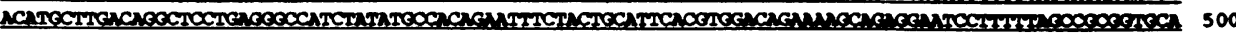

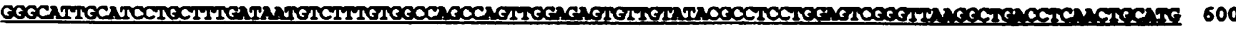

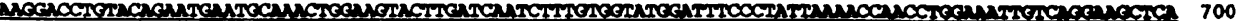

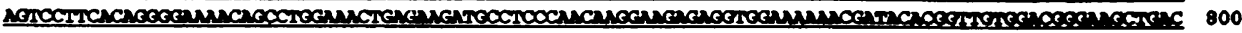

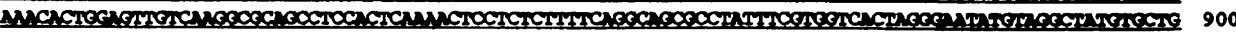

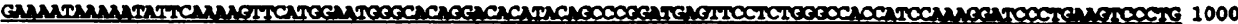

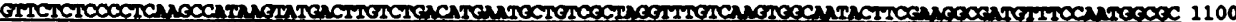

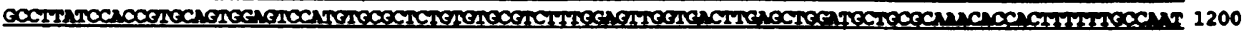

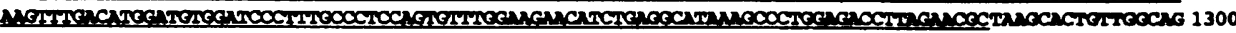
TCCT6еQеNM

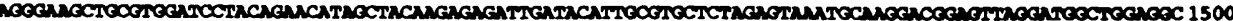

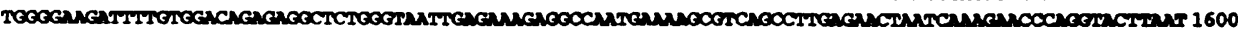

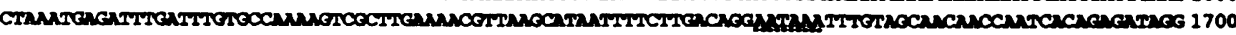

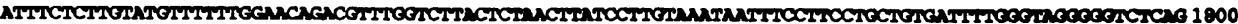

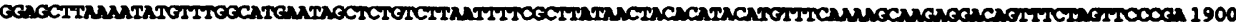

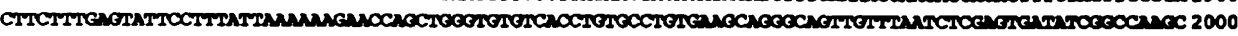

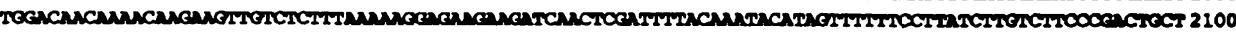

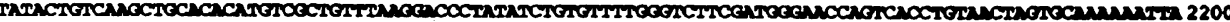

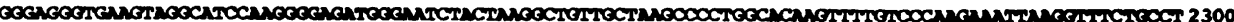

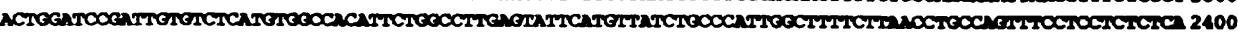

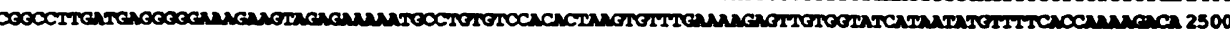

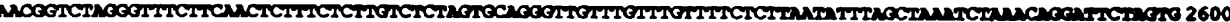

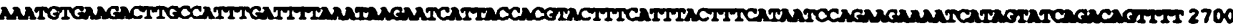

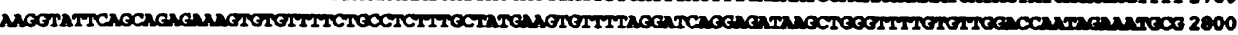

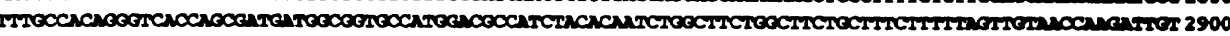

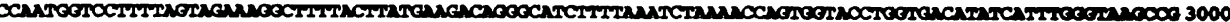

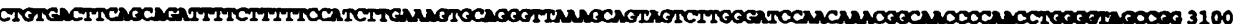

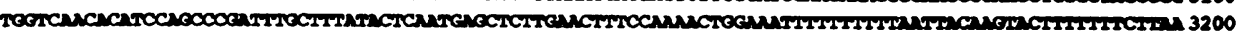

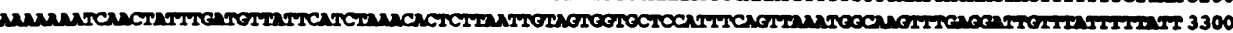

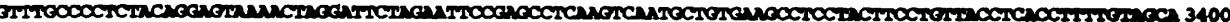

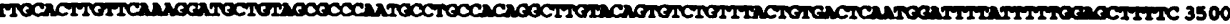

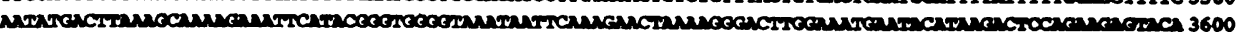

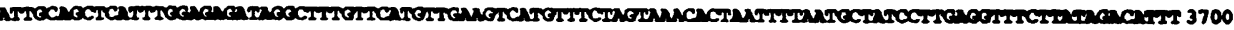

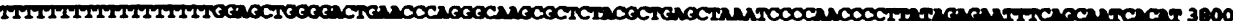

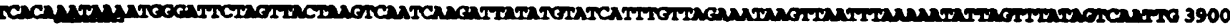

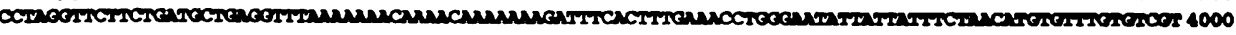

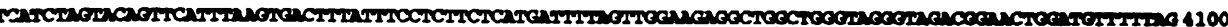

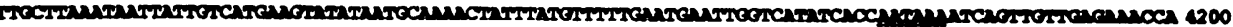
мимимих

B

DI(Ret) MLRLFRRRL FSYPTKYYFY VLVLSLITFS VVRIBQKPEF VSVSHLELSG DDPNSNVNCT House

DII(RAE) KVLQGDPEEI QKVKLEILTV QEKKRPRRTP HEYTWMTRDC ASFIRTRKYI MEPLTKEEVG 120 Fouse

DA1(RAt) FPIAYSIVVE GRIDMIDRLL RAIYMPQNFY CIHVDRKAEE SFLAAVQGIA SCFDNVFVAS 180

House

DEI (Rat) QLESWVYASW SRVRADLNCM KDLYRMNANG KYLINLCGMD FPIKTNLEIV RKLRSFTGEN 240

Hovee

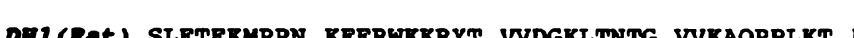

DI1(Rat) SLETEKHPPN REERWKKRYT VVDGKLTNTG VVKAQPPLKT PLFSGSAYFV VTREYVGYVL 300

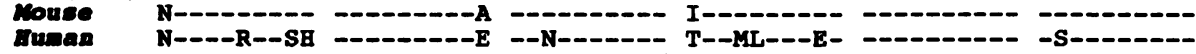

DE1(Rat) ENKNIQRFME WAQDTYSPDE FLWATIQRIP EVPGSLPSSB KYDLSDMNAV ARFVKWQYFE 360

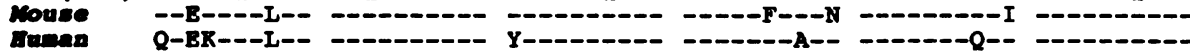

Duman Q-BK--I- -

DII (Rat) GDVSNGAPYP PCSGVHVRSV CVFGVGDLSW MLRRHBFFAN KFDMDVDPFA LQCLEEGLRH

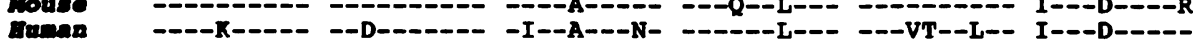

DEL (Rat) RALETLER 428

rouse
Figure 3. Nucleotide and deduced amino acid sequences of $\mathrm{DH} 1$. ( $A$ ), The full-length nucleotide sequence of DH1 is shown. The sequence is numbered relative to presumed start codon. The longest open reading frame (underlined) and putative polyadenylation signal (dashed) are noted. (B), The deduced amino acid sequence of $\mathrm{DH} 1$ is compared with mouse and human (32) core 2 GlcNAc$\mathrm{T}$. The sequences are numbered from the presumed initiation methionine. Dashes represent identical sequences. The putative signal/ membrane-anchoring domain is underlined. 


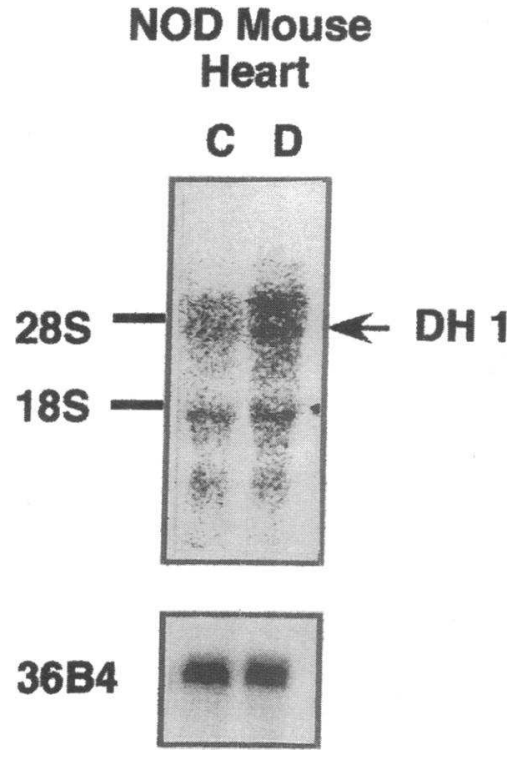

Figure 4. Northern blot analysis of DH1 was performed using $25 \mu \mathrm{g}$ total cellular RNA isolated from age-matched NOD control mice $(C)$ and diabetic NOD mice $(D)$. The same blot was reprobed with 36B4 cDNA as a loading control.

and a polyadenylation signal, AATAAA, was found 15 bp upstream from the polyA tail. Searches for homologous sequences in Genbank/EMBL revealed that this cDNA shared $80 \%$ identity at the nucleotide level and $85 \%$ identity at the amino acid level with human core 2 (GlcNAc-T) (32). We also cloned and sequenced the mouse core 2 GlcNAc-T and found that DH1 shared $92 \%$ identity with the amino acid sequence of mouse core 2 GlcNAc-T (Fig $3 B$ ). These findings strongly suggested that $\mathrm{DH} 1$ was rat core 2 GlcNAc-T.

Characterization of $\mathrm{DHI}$ expression in the NOD mouse. To check that increased expression of DH1 was diabetes specific and not due to other effects of streptozotocin, DH1 expression in the hearts of spontaneous autoimmune-caused diabetic NOD mice was measured. As shown in Fig. 4, DH1 hybridizing signals were detected by Northern blot analysis at 6.0, 4.6, and $1.9 \mathrm{~kb}$ from animals which had experienced $2-3 \mathrm{wk}$ of hyperglycemia and diabetes. The 4.6 and $6.0 \mathrm{~kb}$ bands in hearts from diabetic NOD mice increased to $560 \%$ of control animals.

Effects of insulin on $\mathrm{DHI}$ expression in diabetic rats. After 1 wk of diabetes, four rats were treated with insulin for an additional week. Blood glucose level was normalized from 24.7 to $4.8 \mathrm{mM}(P<0.01)$. The Northern blot analysis shown in Fig. 5, demonstrated that cardiac expression of DH1 in rats diabetic for $2 \mathrm{wk}$ increased to $680 \%$ of control levels, consistent with earlier data, whereas insulin treatment normalized the expression of the DH1 to $169 \%(134-214 \% P<0.001$ vs 2 -wk diabetic rats) of control levels.

Tissue distribution of $\mathrm{DH} 1$. Fig. $6 \mathrm{~A}$ shows a representative Northern blot analysis of DH1 expression using total cellular RNA isolated from tissues of control and diabetic rats. Relative signal intensity was calculated using the 36B4 signal for normalization and is shown in Fig. $6 \mathrm{~B}$. In normal rats, DH1 transcripts were relatively high in the brain, kidney and liver and low in the heart, aorta, lungs, and skeletal (soleus) muscle. A significant and cardiac specific increase (6.8-fold) in the expression of DH1 mRNA was observed in diabetic animals.

The expression of $\mathrm{DH} 1$ in cultured cells. Cultured cardiomyocytes were measured to determine whether they could be the source of the increased expression of DH1. As shown in Fig. $7 A$, DH1 hybridizing signals were detected by Northern blot analysis of cultured cardiomyocytes at the same mobility as the

\section{SD Rat Heart}

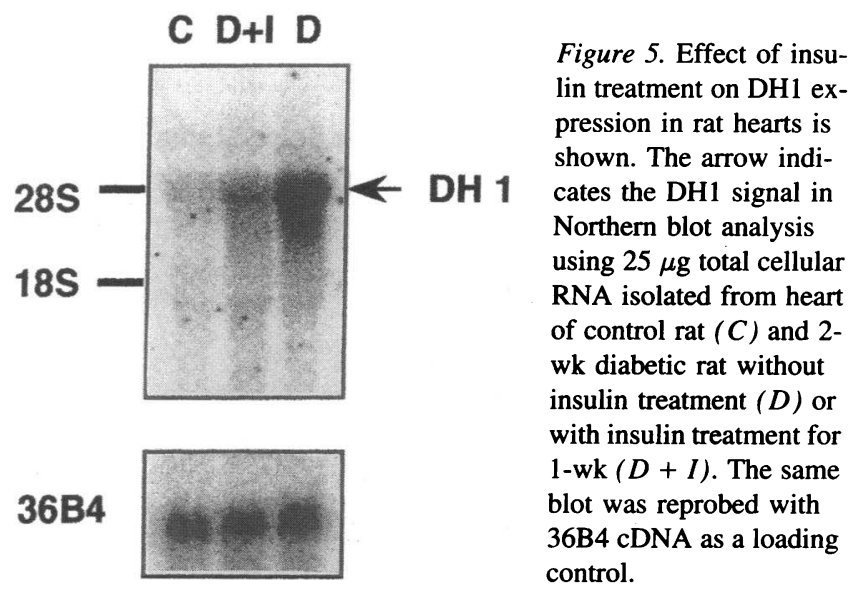

mRNA from heart tissue $(5.0 \mathrm{~kb})$. However, DH1 expression was not detectable in fibroblasts cultured from rat heart or rat aortic smooth muscle cells even when using $25 \mu \mathrm{g}$ of total cellular RNA. Furthermore, in cardiomyocytes, cultures elevating media glucose concentrations from 5.5 to $22 \mathrm{mM}$ increased the expression of the DH1 by $78 \%(54-106 \%, P<0.05)$ while insulin $\left(10^{-7} \mathrm{M}\right)$ decreased the expression by $53 \%(40-62 \%$. $P<0.05$ ) of control levels as shown in Fig. 7 B.

Core 2 GlcNAc-T activity in cells transiently transfected with $\mathrm{DH}$ 1. Although Cos 7 cells lipofected with pcDNAI/amp showed significant endogenous core 2 GlcNAc-T activity of $1.71 \pm 0.27 \mathrm{nmol} / \mathrm{mg}$ per $\mathrm{h}(n=3)$, cells transfected with the expression vector containing a full-length cDNA for DH1 in correct orientation had $3.85 \pm 1.6 \mathrm{nmol} / \mathrm{mg}$ per $\mathrm{h}(P<0.05, n$ $=3$ ). The assay is specific for core 2 GlcNAc-T, as confirmed by analysis of the reaction product $\mathrm{Gal} \beta 1-3$ [GlcNAc $\beta 1-6]$ GalNAc $\alpha$-pNp by 1 H-NMR (Nuclear Magnetic Resonance) and HPLC which had been reported in previous studies (28). Therefore, DH-1 encodes an enzymatically active core-2 GlcNAc-T.

GlcNAc-T activity in heart. With the identification of DH1 being an enzyme involved in mediating the biosynthesis of $O$ linked sugar chains, we tested the specificity of the diabetes effect by measuring the activities of core 2 GlcNAc-T (which branches maturing $O$-linked sugar chains) and two other GlcNAc transferases (which are specific for branching $N$-linked sugar chains) in the hearts of control and diabetic rats (Fig. 8). Core 2 GlcNAc-T activity increased significantly and specifically in diabetic hearts by $82 \%$ of control $(0.39 \pm 0.03$ vs $0.71 \pm 0.10 \mathrm{nmol} / \mathrm{h}$ per $\mathrm{mg}$ protein $n=3, P<0.05$ ). In contrast, GlcNAc-TI and GlcNAc-TV activities were not significantly different between control and diabetes (GlcNAc-TI:1.05 \pm 0.11 vs $0.79 \pm 0.09 \mathrm{nmol} / \mathrm{h}$ per $\mathrm{mg}$ protein, GlcNAc-TV: $0.078 \pm 0.024$ vs $0.077 \pm 0.023 \mathrm{nmol} / \mathrm{h}$ per $\mathrm{mg}$ protein). The changes thus seem restricted to $O$-glycosylation.

\section{Discussion}

Multiple studies have reported metabolic and functional alterations in the heart of animals with a short duration of diabetes $(6,7)$. With chronic duration of diabetes, structural changes in the vasculature and increased carbohydrate content of the heart, denoted by an increase in periodic acid-Schiff (PAS) staining 
A

Aorta Brain Heart Kidney Liver Soleus Lung C D C D C D C D C D C D C D

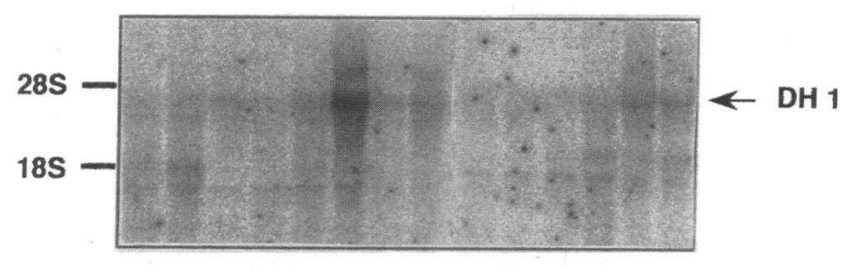

$36 \mathrm{~B} 4$

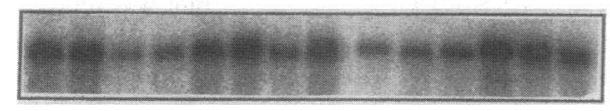

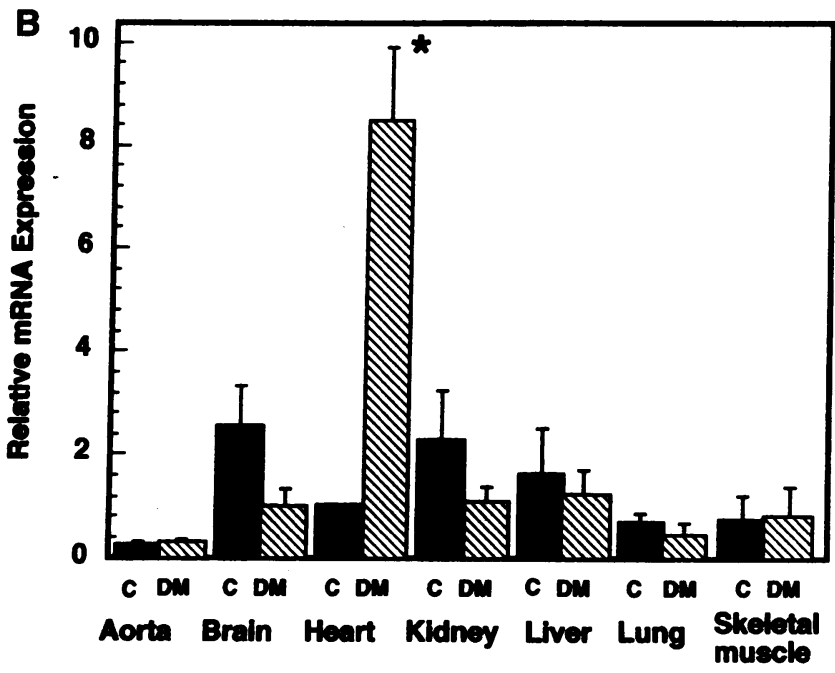

Figure 6. Tissue distribution of gene expression of DH1 is shown. (A), Northern blot analysis was performed using $20 \mu \mathrm{g}$ total cellular RNA isolated from aorta, brain, heart, kidney, liver, soleus muscle, and lung of control $(C)$ and 2-wk diabetic $(D)$ rats. DH1 signals are indicated by an arrow. The same blot was reprobed with 36B4 cDNA as a loading control. $(B)$ Quantitation of changes induced by diabetes mRNA level for DH1 in aorta, brain, heart, kidney, liver, lung, and skeletal muscle. Data are expressed relative to the message level of control rat heart. Closed bars represent control $(C)$ and hatched bars represent 2 -wk diabetes $(D M)$. Results are shown as mean \pm SE of three experiments using different animals. $* P<0.05$ as compared with control.

are indicative of less reversible alterations $(5,8,9,33)$. Changes in the expression of glucose transporter (GLUT-4) (34), $\mathrm{Ca}^{2+}$ ATPase (35), and alpha- and beta-adrenergic receptors (7) have been reported in the diabetic state and have been suggested as possible candidates causing acute cardiac dysfunctions. However, it is unlikely that these changes are directly responsible for the chronic and structural changes since their biological actions are transient and their relationship to the in-

A

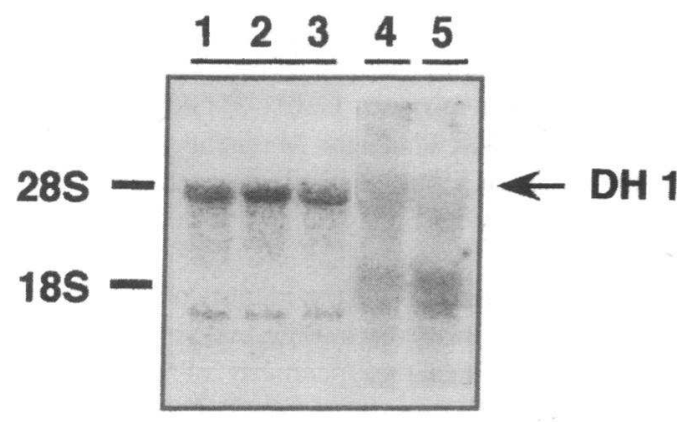

36B4

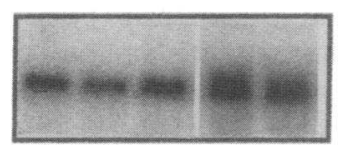

\section{B}

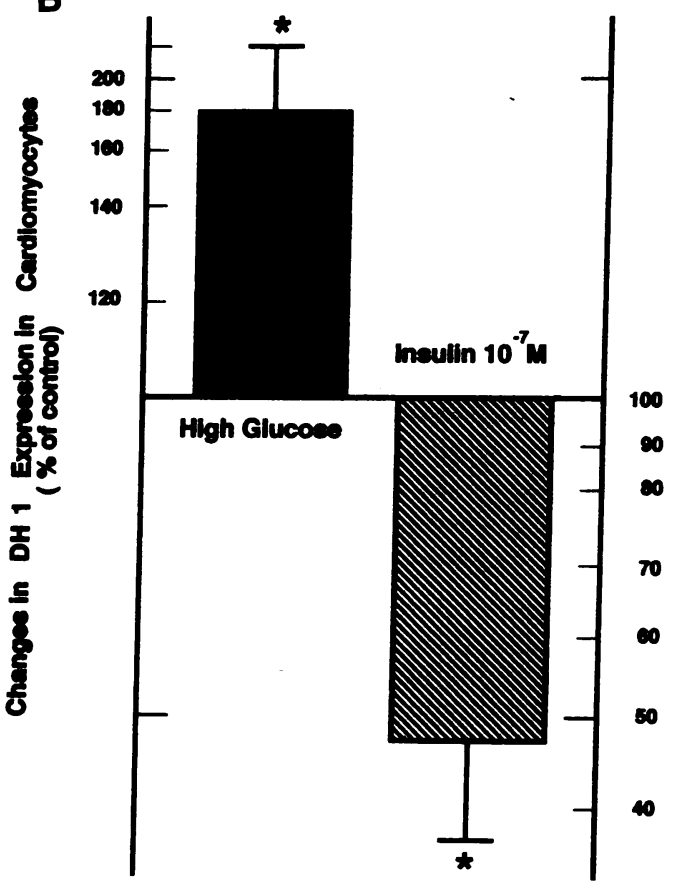

Figure 7. Northern blot analysis of DH1 mRNA. (A) Total cellular RNA from cultured cardiomyocytes ( $10 \mu \mathrm{g}$ ) for lanes $1-3$, fibroblasts (25 $\mu \mathrm{g}$ ) for lane 4, and rat aortic smooth muscle cells $(25 \mu \mathrm{g})$ for lane 5 were used. Cardiomyocytes were cultured as described in Methods with 5.5 $\mathrm{mM}$ glucose without insulin $(C), 22 \mathrm{mM}$ glucose without insulin $(H G)$, or $5.5 \mathrm{mM}$ glucose with $100 \mathrm{nM}$ insulin $(I)$ for $3 \mathrm{~d}$. DH1 signals are indicated by an arrow. The same blot was reprobed with 36B4 cDNA as a loading control. ( $B$ ) Quantitation of changes induced by $22 \mathrm{mM}$ glucose or $100 \mathrm{nM}$ insulin for DH1 expression in cultured cardiomyocytes. Data are expressed as percentage of control. Closed bar represents the results of cells cultured with $22 \mathrm{mM}$ glucose and hatched bar represents the result of cells cultured with $100 \mathrm{nM}$ insulin. Results are shown as mean $\pm \mathrm{SE}$ of four independent experiments. ${ }^{*} P<0.05$ as compared with control. 


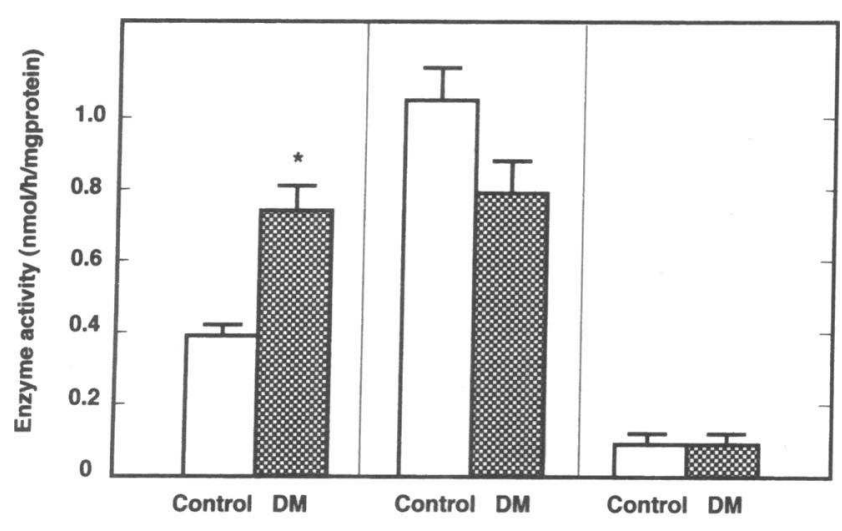

Core 2 GIcNAc-TI GIcNAc-TV

Figure 8. GlcNAc-T activities in the heart of control (closed column) and 2-wk diabetic (hatched column) rats. Core 2 GlcNAc-T, GlcNAcTI, and -TV activities were measured as described in Methods Results are presented as mean \pm SE of three measurements using different animals. $* P<0.05$ as compared with control.

crease in PAS staining is not obvious. To discover new candidate genes which may be responsible for causing diabetic cardiac dysfunction, we have used mRNA differential display to screen for alteration of gene expression in the cardiac ventricles of diabetic rats.

In the present study, eight possible candidate genes were suggested by the initial screening of $\sim 2,000$ mRNA species and two of the eight showed reproducible differences in expression by Northern blot analysis, a rate of confirmed positives similar to that reported in previous studies $(17,18)$. Genes previously identified as altered in the diabetic state such as GLUT-4 (34) and $\mathrm{Ca}^{2+}$ ATPase (35) mRNA were not observed in this study, however, this may be due to several potential limitations of the differential display method such as the insensitivity of this method to quantitate small changes in gene expression as compared with Northern blot analysis and differences in primer efficiencies. Alternatively, it is also possible that not all the potential mRNA species have been compared since only $\sim 2,000$ were analyzed. Previous studies using this method to identify glucose regulated genes in the vascular cells showed that genes with as little as twofold change in mRNA and consequent protein levels can be detected (18).

The sequence of clone 13 was identified as $99 \%$ identity to mitochondria 16S ribosomal RNA (30). At present, the significance of a change in mitochondrial ribosomal RNA to the development of cardiovascular abnormalities in diabetes is not clear. However, mitochondrial swelling has been observed in early stage of diabetic rats and preceded the abnormalities in cardiac function and histology which occurred after 4-8 wk and 1224 wk of diabetes, respectively (36-38). Altered gene expression in the mitochondria could be due to changes in glucose metabolism and rates of oxidative phosphorylation in the cardiomyocytes of diabetic rats (39). Since all mitochondrial genes are regulated in a similar manner with a common promoter region (40), this finding would suggest that diabetes should affect them all equally and may have significant effect on mitochondrial functions, which could possibly decrease cardiac functions.

Clone DH1 encoded an open reading frame and analysis of its complete cDNA sequence inferred polypeptide showed $85 \%$ identity with human core 2 GlcNAc-T and $92 \%$ identity to the murine enzyme. The high degree of homology between DH1 and mouse core 2 GlcNAc-T is similar to that observed for other glycosyltransferase homologues of rat and mouse (41). Furthermore, the identity of the DH1 cDNA was confirmed by the transient transfection in Cos-7 cells which produced core 2 GlcNAc-T activity. Northern blot analysis showed three species of messages $(5,4.7$, and $2 \mathrm{~kb})$ similar to that previously reported for core 2 GlcNAc-T in human lymphoid cells (32). Since preliminary data from our laboratory has shown that the coding region of the gene at the genomic level is uninterrupted, suggesting that alternately spliced $5^{\prime}$ or $3^{\prime}$ untranslated regions account for the multiple messages. Three polyadenylation sequences were identified and correspond to the message sizes observed by Northern blot analysis. The 100 nucleotides preceding the most distal poly $\mathrm{A}$ adenylation signal were conserved in mouse and rat sequences. The unusually long 3 '-noncoding region may affect message half life as observed in other systems (42). The finding of multiple sizes of messages in the mouse heart is consistent with the finding of multiple possible termination sites.

Since the antibody to rat core 2 GlcNAc-T is not available at the present time, it is not possible to determine whether the increase in the gene expression of this enzyme is translated into protein level directly. However, the finding that core 2 GlcNAc$T$ activity was doubled in hearts from diabetic rats compared to control animals supports this suggestion. Core 2 GlcNAc-T is a key enzyme in the $O$-linked glycosylation pathway which utilizes UDP-GlcNAc and substitutes Gal $\beta 1-3$ GalNAc-R at the 6 position of GalNAc. This results in Gal $\beta 1-3$ [GlcNAc $\beta 1-$ 6] GalNAc-R, a branched oligosaccharide which is commonly extended with polylactosamine chains and Lewis antigens. The latter sequences on $O$-linked oligossacharides participate in leukocyte adhesion and homing, and are deficient in pathologic conditions, where core 2-GlcNAc-transferase expression is suppressed, such as leukemia (43), AIDS (44), and Wiskott-Aldrich syndrome (45). Furthermore, Datti et al. reported that this enzyme activity was induced by butyrate differentiation of Chinese hamster ovary cells, following an increase in intracellular cAMP level (27). Although it is presently unclear whether increased core 2 GlcNAc-T activity causes pathology in the heart of diabetic rats, it is possible that the additional branches and their sialylation results in the accumulation of PAS-positive material commonly observed in diabetic hearts. In fact, Reagan et al. and other investigators have emphasized that the accumulation of PAS-positive material in the interstitium opposing the surface of the cardiac fibers may compromise cardiac function (5). Further study with a longer duration of diabetes will be needed to determine the relationship between the increase of PAS-positive material and induction of core 2 GlcNAc-T in the cardiac tissue.

The increase in the expression of core 2 GlcNAc-T (DH1) by diabetes was very tissue specific involving only the heart among the various tissues studied. Similarly, core 2 GlcNAc$\mathrm{T}$ message was observed in cultured cardiomyocytes but not in fibroblasts derived from cardiac tissue or aortic smooth muscle cells. The cardiac specificity of core 2 GlcNAC-T induction by diabetes and glucose contrasts with previous reports on the induction of extracellular matrix genes such as type I or IV collagen, where the changes were similar in all tissues examined including retina (46), kidney (47), and many types of cultured cells $(13,14)$. Since the clinical patterns of cardiomyopathy appear to be distinct from other diabetic vascularopathies, our 
findings of tissue-specific changes in the gene expression suggest that the promoter of DH1 may contain cardiac-specific core 2 GlcNAc-T promoter elements which can be modulated by metabolic factors such as hyperglycemia and insulin.

Several observations from our study strongly suggest a role for metabolic regulation of core 2 GlcNAc-T in diabetic conditions. First, the up-regulation of core $2 \mathrm{GlcNAc-T}$ is not due to streptozotocin or limited to rats since the same finding was also observed in the NOD mouse. Second, hyperglycemia regulates this enzyme directly. These findings suggest that core 2 GlcNAc-T is involved in diabetic cardiovascular complication and also shows that enzymes involved in glycosylation can be regulated by hyperglycemia. Further studies are needed to delineate the mechanism by which hyperglycemia can regulate core 2 GlcNAc-T expression. One possible mechanism is the activation by the diacylglycerol-protein kinase C (DAG-PKC) pathway since previous studies have reported that hyperglycemia and diabetes increased DAG levels and activated PKC in the heart of diabetic animals including the rat (13), and phorbol ester, a PKC agonist, has been reported to regulate core 2 transferase activity (27). Cloning and sequencing of the core 2 GlcNAc-T promoter regions is in progress to clarify this particular question.

In addition to changes directly related to hyperglycemia, insulin also decreased core 2 GlcNAc-T gene expression both in vivo and in cultured cardiomyocytes, suggesting that insulin may modulate its expression both directly and by improving glycemic control. It is not surprising that insulin was shown to affect gene expression in the heart since multiple studies have documented that myocardium is responsive to insulin at biochemical and physiological levels $(34,48)$. Clinically, insulin treatment has been reported to improve cardiac function in diabetic patients (49). At the molecular level, a great deal of information is available on insulin's action on gene regulation, not specifically on cardiomyocytes (50). Therefore, further studies in the sequence of the $5^{\prime}$ region may provide information whether it contains the various insulin responsive elements which have already been reported (50). Similarly, other hormones and cytokines such as IGFs (51) and thyroxine (52), which are known to affect cardiac function, may also affect core 2 GlcNAc-T expression and will need to be characterized.

In summary, we have identified two novel molecular alterations in the myocardia of diabetic rats at the level of gene expression. One of these genes has been identified as core 2 GlcNAc-T, and provides strong evidence that hyperglycemia and insulin can regulate enzymes involved in the glycosylation of proteins, specifically in the heart. Thus, we have identified a possible mechanism for the pathology of increased carbohydrates in the myocardium of diabetic rats and patients, which in turn could affect cardiac function.

\section{Acknowledgments}

We are grateful to Chris Feener for useful technical advice for making and screening cDNA library, to Dr. Masakazu Hattori for the kind gift of NOD mouse, to Dr. C. Ronald Kahn for helpful discussions, to the members of our laboratory for advice and support, and to Leslie Balmat for secretarial assistance.

This work was supported by National Institutes of Health grants EY05110 (G.L. King), Diabetes Education and Research Center grant DK36836, DK36433 (G.L. King), HL20476 (T.B. Miller, Jr.). In addition, the authors wish to acknowledge the contributions of Dr. O. Hindsgaul for GlcNAc-TV acceptor, Dr. A. Datti for the human core 2 GlcNAc probe, and funding support from National Cancer Institute, Canada (C.E.
Wasren and J.W. Demis) and the Juvenile Diabetes Foundation (G.L. King).

\section{References}

1. Kessler, I. I. 1971. Mortality experience of diabetic patients. Am. J. Med. 51:715-724.

2. Rubler, S., J. Dlugash, Y. Z. Yuceoglu, T. Kumral, A. W. Branwood, and A. Girshman. 1972. New type of cardiomyopathy associated with diabetic glomerulosclerosis. Am. J. Cardiol. 30:595-602.

3. Kannel, W. B., M. Hjoltland, and W. P. Castelli. 1974. Role of diabetes in congestive heart failure: the Framingham study. Am. J. Cardiol. 34:29-34.

4. Lababidi, Z. A., and D. E. Goldstein. 1983. High prevalence of echocardiographic abnormalities in diabetic youths. Diabetes Care. 6:18-22.

5. Reagan, T. J., P. O. Ettinger, M. I. Khan, M. U. Jesrani, M. M. Lyons, H. A Oldewurtel, and M. Weber. 1974. Altered myocardial function and metabolism in chronic diabetes mellitus without ischemia in dogs. Circ. Res. 35:222-237.

6. Fein, F. S., J. E. Strobeck, A. Malhotra, J. Scheuer, and E. H. Sonnenblick 1981. Reversibility of diabetic cardiomyopathy with insulin in rats. Circ. Res. 49:1251-1261.

7. Nishio, Y., A. Kashiwagi, Y. Kida, M. Kodama, N. Abe, Y. Saeki, and Y. Shigeta. 1988. Deficiency of cardiac B-adrenergic receptor in streptozocin-induced diabetic rats. Diabetes. 37:1181-1187.

8. Reagan, T. J., M. M. Lyons, S. S. Ahmed, G. E. Levinson, H. A. Oldewurtel, M. R. Ahmad, and B. Haider. 1977. Evidence for cardiomyopathy in familial diabetes mellitus. J. Clin. Invest. 60:885-899.

9. Factor, S. M., T. Minase, and E. H. Sonnenblick. 1980. Clinical and morphological features of human hypertensive-diabetic cardiomyopathy. Am. Heart J. 99:446-458.

10. Engerman, R. J., and T. S. Kern. 1987. Progression of incipient diabetic retinopathy during good glycemic control. Diabetes. 36:808-812.

11. Inoguchi, T., R. Battan, E. Handler, J. R. Sportsman, W. Heath, and G. L. King. 1992. Preferential elevation of protein kinase C isoform BII and diacylglycerol level in the aorta and heart of diabetic rats: differential reversibility to glycemic control by islet cell transplantation. Proc. Natl. Acad. Sci. USA. 89:11059-11063.

12. Nishio, Y., A. Kashiwagi, T. Ogawa, T. Asahina, M. Ikebuch, M. Kodama, and Y. Shigeta. 1990. Increase in $\left[{ }^{3} \mathrm{H}\right]$ PN200-110 binding to cardiac muscle membrane in streptozocin-induced diabetic rats. Diabetes. 39:1064-1069.

13. Cagliero, E., M. Maiello, D. Boeri, S. Roy, and M. Lorenzi. 1988. Increased expression of basement membrane components in human endothelial cells cultured in high glucose. J. Clin. Invest. 82:735-738.

14. Ayo, S. H, R. A. Radink, W. F. Glass II, J. A. Garoni, E. R. Rampt, D. R. Appling, and J. L. Kreisberg. 1990. Increased extracellular matrix synthesis and mRNA in mesangial cells grown in high-glucose medium. Am. J. Pathol. 136:1339-1348.

15. Liang, P., and A. B. Pardee. 1992. Differential display of eukaryotic messenger RNA by means of polymerase chain reaction. Science (Wash. DC) 257:967-971.

16. Liang, P., L. Averboukh, K. Keyomarsi, R. Sager, and A. B. Pardee. 1992. Differential display and cloning of messenger RNAs from human breast cancer versus mammary epithelial cells. Cancer Res. 52:6966-6968.

17. Nishio, Y., L. P. Aiello, and G. L. King. 1994. Glucose induced genes in bovine aortic smooth muscle cells identified by mRNA differential display. FASEB (Fet. Am. Soc. Exp. Biol.) J. 8:103-106.

18. Aiello, L. P., G. S. Robinson, Y. W. Lin, Y. Nishio, and G. L. King. 1994. Identification of multiple glucose-regulated genes in bovine retinal pericytes by mRNA differential display. Proc. Natl. Acad. Sci. USA. 91:6231-6235.

19. Ikegami, H. G. S. Eisenbarth, and M. Hattori. 1991. Major histocompatibility complex-linked diabetogenic gene of the nonobese diabetic mouse. Analysis of genomic DNA amplified by the polymerase chain reaction. J. Clin. Invest. 85:18-24.

20. Klickstein, L. B., and L. R. Nerve. 1991. Construction of recombinant DNA libraries. In Current Protocols in Molecular Biology. F. M. Ausubel, R. Brent, R. E. Kingston, D. D. Moore, J. G. Seidman, J. A. Smith, and K. Struhl, editors. John Wiley \& Sons, New York. 5.0.1-5.6.10.

21. Maniatis, T., E. F. Fritsh, and J. Sambrook. 1982. Molecular Cloning Cold Spring Harbor Laboratory, Cold Spring, NY.

22. Dennis, J. W. 1985. Different metastatic phenotypes and two genetic classes of wheat germ agglutinin-resistant tumor cell mutants. Cancer Res. 46:4594-4600.

23. Weis, J. H. 1991. Plating and transferring cosmid and plasmid library. In Current Protocols in Molecular Biology. F. M. Ausubel, R. Brent, R. E. Kingston, D. D. Moore, J. G. Siedman, J. A. Smith, and K. Struhl, editors. John Wiley \& Sons, New York. 6.2.1-6.2.3.

24. Felgner, P. L., T. R. Gadek, M. Holm, R. Roman, H. W. Chan, M. Wenz, J. P. Northrup, G. M. Ringold, and M. Danielsen. 1987. Lipofection: a highly efficient, lipid-mediated DNA transfection procedure. Proc. Natl. Acad. Sci. USA. 84:7413-7417.

25. Buczek-Thomas, J. A., S. R. Jaspers, and T. B. Miller, Jr. 1992. Adrenergic 
activation of glycogen phosphorylase in primary culture diabetic cardiomyocytes. Am. J. Physiol. 262:H649-H653.

26. Willams, D., and H. Schachter. 1980. Mucin synthesis. I. Detection in canine submaxillary glands of an $\mathrm{N}$ - acetyglucosaminyltransferase which acts on mucin substrates. J. Biol. Chem. 255:11247-11252.

27. Datti, A., and J. W. Dennis. 1993. Regulation of UDP-GlcNAc:GalB13GalNAc-R B1-6-N-acetylglucosaminyltransferase (GlcNAc to GalNac) in Chinese hamster ovary cells. J. Biol. Chem. 268:5409-5416.

28. Yousefi, S., E. Higgins, Z. Doaling, O. Hindsgaul, A. Pollex-Kruger, and J. W. Dennis. 1991. Increased UDP-GlcNAc:Gal B1-3GalNAc-R (GlcNAc to GalNac) B1-6 N-acetylglucosaminyltransferase activity in transformed and metastatic murine tumor cell lines: control of polylactosamine synthesis. J. Biol. Chem. 266:1772-1783.

29. Moller, G., F. Reck, H. Paulsen, K. J. Kaur, M. Sarkar, H. Schachter, and I. Brockhausen. 1992. Control of glycoprotein synthesis: substrate specificity for rat liver UDP-GlcNAc:Man $\alpha 3 \mathrm{R}$ B2-N-acetylglucosaminyl-transferase I using synthetic substrate analogues. Glycoconj. J. 9:180-190.

30. Kobayashi, M., T. Seki, K. Yaginuma, and K. Koike. 1981. Nucleotide sequences of small ribosomal RNA and adjacent transfer RNA genes in rat mitochondrial DNA. Gene. 16:297-307.

31. Carvener, D. R., and S. C. Ray. 1991. Eukaryotic start and stop translation sites. Nucleic Acids Res. 19:3185-3192.

32. Bierhuizen, M. F., and M. Fukuda. 1992. Expression cloning of a cDNA encoding UDP-GlcNAc:GalB1-3GalNAc-R(GlcNAc to GalNAc) B1-GlcNAc transferase by gene transfer into $\mathrm{CHO}$ cells expressing polyoma large tumor antigen. Proc. Natl. Acad. Sci. USA. 89:9326-9330.

33. Ledet, T. 1961. Histological and histchemical changes in the coronary arteries of old diabetic patients. Diabetologia. 4:268-272.

34. Camps, M., A. Castello, P. Munoz, M. Monfar, X. Testar, M. Palacin and A. Zorzano. 1992. Effect of diabetes and fasting on GLUT-4 (muscle/fat) glucose-transporter expression in insulin-sensitive tissue. Heterogeneous response in heart, red and white muscle. Biochem. J. 282:765-772.

35. Zarain, H. A., K. Yano, V. Elimban, and N. S. Dhalla. 1994. Cardiac sarcoplasmic reticulum $\mathrm{Ca}^{2+}$-ATPase expression in streptozotocin-induced diabetic rat heart. Biochem. Biophys. Res. Commun. 203:113-120.

36. Hsiao, Y. C., K. Suzuki, H. Abe, and T. Toyota. 1987. Ultrastructural alterations in cardiac muscle of diabetic BB Wistar rats. Virchows. Arch. A. Pathol. Anat. Histopathol. 411:45-52.

37. Reinila, A., and H. K. Akerblom. 1984. Ultrastructure of heart muscle in short-term diabetic rats: influence of insulin treatment. Diabetologia. 27:397402

38. Jackson, C. V., G. M. McGrath, A. G. Tahiliani, R. V. Vadlamudi, and
J. H. McNeill. 1985. A functional and ultrastructural analysis of experimental diabetic rat myocardium. Manifestation of a cardiomyopathy. Diabetes. 34:876883.

39. Kuo, T. H., K. H. Moore, F. Giacomelli, and J. Wiener. 1983. Defective oxidative metabolism of heart mitochondria from genetically diabetic mice. Diabetes. 32:781-787.

40. Clayton, D. A. 1984. Transcription of the mammalian mitochondrial genome. Annu. Rev. Biochem. 53:573-594.

41. Lee, Y.-C., N. Kojima, E. Wada, N. Kurosawa, T. Nakaoka, T. Hamamoto, and S. Tsuji. 1994. Cloning and expression of cDNA for a new type of Gal $\beta 1,3-$

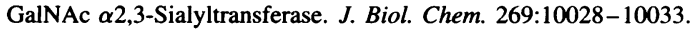

42. Sachs, A. B. 1993. Messenger RNA degradation in eukaryotes. Cell. 74:413-421.

43. Brockhausen, I., W. Kuhns, H. Schachter, K. L. Matta, D. R. Sutherland, and M. A. Baker. 1991. Biosynthesis of O-glycans in leukocytes from normal donors and from patients with leukemia: Increase in O-glycan core 2 UDPGlcNAc:GalB3GalNAc-R (GlcNAc to GalNAc) B(1-6)-N-acetylglucosaminyltransferase in leukemic cells. Cancer Res. 51:1257-1263.

44. Saitoh, F., F. Piller, R. I. Fox, and M. Fukuda. 1991. T-lymphocytic leukemia expresses complex branched O-linked oligosaccharides on a major sialoglycoprotein, Leukosialin. Blood. 77:1491-1499.

45. Piller, F., F. L. Deist, K. I. Weinberg, R. Parkman, and M. Fukuda. 1991 Altered O-glycan synthesis in lymphocytes from patients with Wiskott-Aldrich Syndrome. J. Exp. Med. 173:1501-1510.

46. Roy, S., M. Maiello, and M. Lorenzi. 1994. Increased expression of basement membrane collagen in human diabetic retinopathy. J. Clin. Invest. 93:438-442.

47. Fukui, M., T. Nakamura, I. Ebihara, I. Shirato, Y. Tomino, and H. Koide. 1992. ECM gene expression and its modulation by insulin in diabetic rats. Diabetes. 41:1520-1527.

48. Shanker, R., W. E. Neeley, and W. H. Dillmann. 1986. Rapid effects of insulin on in vitro translational activity of specific mRNA in diabetic rat heart. Am. J. Physiol. 250:E558-E563.

49. Page, M. M., R. B. Smith, and P. J. Watkins. 1976. Cardiovascular effects of insulin. Br. Med. J. 1:430-432.

50. O'Brien, M. R., and D. K. Granner. 1990. PEPCK gene as model of inhibitory effects of insulin on gene transcription. Diabetes Care. 13:327-339.

51. Bornfeldt, K. E., A. Skottener, and H. J. Arnqvist. 1992. In vivo regulation of messenger RNA encoding insulin-like growth factor-I (IGF-I) and its receptor by diabetes, insulin and IGF-I in rat muscle. J. Endocrinol. 135:203-211.

52. Dillmann, W. H. 1989. Diabetes and thyroid-hormone-induced changes in cardiac function and their molecular basis. Annu. Rev. Med. 40:373-394. 